\title{
Creating Value by Designing: Economic and Business Perspectives
}

Dr. Marcin Chłodnicki

Department of Services Management
m.chlodnicki@uepoznan.pl
Dr. MarekZieliński
Department of Marketing Strategies
m.zielinski@ue.poznan.pl
PoznańUniversity of Economics
Al. Niepodlegtości10 PL 61-875 Poznań

Abstract Design is more often used by companies in creation of new business and implementation products and services on the market. In our paper we present design as value creating factor. This paper is based on the fallowing thesis:

Submitted:December, 2008

$1^{\text {st }}$ revision: March, 2009

Accepted: June, 2009

- Design is a success driver for most of businesses - still underestimated.

- Businesses shell use design on project basis or employ it as an integral part of management.

- Creation of value by (using) design can be taken for development of entire nations.

These statements are described and verified with a intellectual argument.

Keywords: Institutions: Design, Formation, and Operations, Innovation and Invention: Processes and Incentives, Management of Technological Innovation and R\&D, Technological Change: Choices and Consequences; Diffusion Processes, Industrialization; Manufacturing and Service Industries; Choice of Technology

JEL classification: D02, O31, O32, O33, O14

\section{Introduction}

What is a goal of this paper? Why was it worth to write it? This paper is based on the following statements:

- Design is a success driver for most of businesses - still underestimated.

- Businesses shell use design on project basis or employ it as an integral part of management.

- Creation of value by (using) design can be taken for development of entire nations.

The above statements will be described and verified with a intellectual argument. 
Why shell one read it? What shell one get by reading it? This article is assumed to endow the reader with:

- Understanding the role of design in success of businesses.

- Possibility of relating ones business to global phenomenon of design.

- Imagine a design opportunity, a potential design situation for ones business.

\section{Understanding design in value creation. Definition of design.}

Design is a human activity that started with the first steps taken by mankind when they attempted to change their environment for their convenience or to make the first tool to enhance their ability to do some work or to protect themselves. It is a product of thought and deliberate action that is driven by intentions and imagination. Design evolved gradually and reached a very high degree of refinement and resolution in our villages and living spaces of our traditional societies in the pre-industrial age (Ranjan, 2009, p.1)

Today this kind of design, at a fundamental level of form-giving, has all but been forgotten by the mainstream and it is replaced by a form of professional activity that is seen as dealing more with aesthetics rather than with the fundamental structure and meaning production systems of our society. This needs to change in an era where science and technology are being placed at the hub of our decision making pathways when they can only provide information and knowledge about the world and not about what is desirable to be done to the world (Ranjan, 2009, p.2).

Design as it is now being understood at the strategic level of application is a modern human activity that can help create the products and services of the future within the constraints of our context. The future is unknowable by any scientific investigation but it can be envisaged and chosen by us through the use of design visualisation and the application of design judgment.

According to Harrold Nelson and Eric Stolterman in their very readable book "The Design Way", the process of design is the path of human intentions being pursued by the designer or user of design through the stages of exploration, composition, judgment and action (Nelson, Stolterman, 2003). The stages are iterative and the designer revisits the previous stages to develop conviction and build support for the next move forward towards the articulation of the design form and structure.

Design, unlike science and technology, is not about finding a fundamental truth or about finding what is possible with a material, situation or context. It is about the realisation of our intentions in a desirable manner that can give us a better future, even if the future that we seek is indeed, unknowable (Ranjan, 2009, p.3).

Dick Buchanan offered his formal definition of design: "Design is the human power to conceive, plan, and realize products that serve human beings in the accomplishment of any individual or collective purpose.” (Margolin, Buchanan, 1996). This was a formal definition, meaning it is fairly rigorous and fairly dry. There are other, descriptive definitions that are more lively: "Design is making things right" of Ralph Kaplan or an explanation given by Steve Jobs: "Design is not just what it looks like and feels like. Design is how it works". There is a number authors expressing their emotions about false opinions and stereotypes existing around category of design. Jeff Neen calls, in open words “I've been amazed at how often those outside the discipline of design assume that what designers do is decoration. Good design is problem solving."

Ellie Runcie, National Programme Leader of the Design Council, comes with the following statement on design (Runcie, 2009): "If creativity is about the generation of new ideas and innovation is about bringing those ideas successfully to market, then design is the process that links the two. It's a process that helps you shape propositions, to make them 
practical but also desirable to customers and end users. It's the tool that will actually make things memorable”.

Dictionaries provide more functional explanations of what design is. A design may also have to satisfy restrictions on the design process itself, such as its length or cost, or the tools available for doing the design $(6,2009)$. Consequently, the design process is the approach that engineering (and some other) disciplines use to specify how to create or do something. A successful design must satisfy a (perhaps informal) functional specification (do what it was designed to do); conforms to the limitations of the target medium (it is possible to implement); meets implicit or explicit requirements on performance and resource usage (it is efficient enough).

Design is a very rich term, takes part in many areas of human life, exists among many disciplines and its full (re)interpretation seems impossible. However, limiting ourselves to only purposeful exploration might give some better understanding on the topic, and allow to synthesize some key characteristics of the phenomenon of design. Design will be found or described as:

- Interdisciplinary / Intermediary,

- Act or outcome of an act,

- Creative solution / problem solving,

- Reasonable process.

Complexity of businesses today push up this function on the strategic level (Strategic Design) expecting holistic approach towards:

- Business solutions through design,

- Design - total image management,

- Design of retail environment - part of marketing concept,

- Design as synergy of unique skills,

- Design spend must have a return (design is an investment).

What are the design subjects? Design subjects include: architecture, product/industrial design, clothing/ fashion design, digital/ multimedia design and graphical/ communication design (Livesey, Molutrie, 2009, p.16).

What is then good design? Good design in most businesses is one that:

- Generates positive RoI (Return on Investment),

- Creates great customer experience,

- Induces purchase decision,

- Reinforces heritage and values,

- Reinforces and creates brand attributes,

- Is educational,

- Is fun and memorable,

- Adds value to the brand.

What is service design?

It's a design specialism that helps develop and deliver great services. Service design projects improve factors like ease, satisfaction, loyalty and efficiency right across areas such as environments, communications and products - and not forgetting the people who deliver the service (King, Heapy, 2009). Service design begins with understanding, what one is trying to make better, why one wants to make it better and how it could best serve people's needs. Service designers help to imagine a variety of solutions and decide which would be most appropriate. They show how to make the new service idea come to life through the things that users of the service would experience, and help to understand what needs to happen behind the scenes to ensure the service performs well (King, Heapy, 2009). 
Chart 1. Visual map of meanings and associations of term: Design

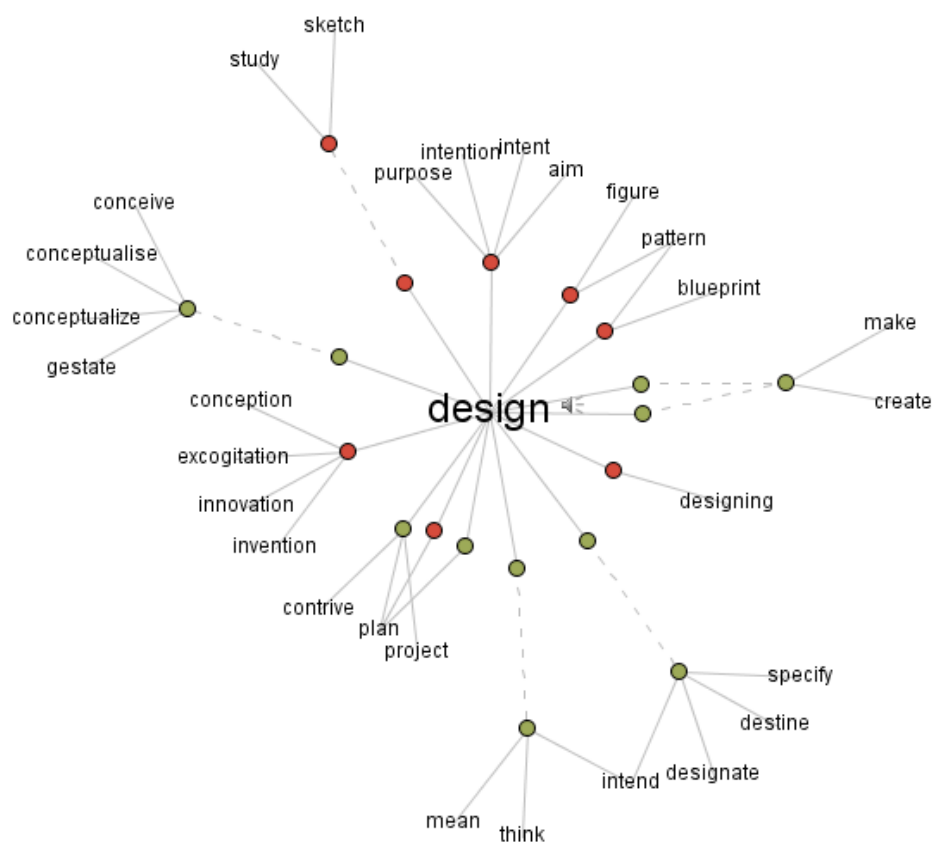

(7, 2009)

\section{Nouns : design}

- the creation of something in the mind

- a preliminary sketch indicating the plan for something "the design of a building"

- an anticipated outcome that is intended or that guides your planned actions

"his intent was to provide a new translation"; "good intentions are not enough"; "it was created with the conscious aim of answering immediate needs"; "he made no secret of his designs"

- a decorative or artistic work "the coach had a design on the doors"

- something intended as a guide for making something else

"a blueprint for a house"; "a pattern for a skirt"

- an arrangement scheme "the awkward design of the keyboard made operation difficult";

"it was an excellent design for living"; "a plan for seating guests"

- the act of working out the form of something (as by making a sketch or outline or plan)

"he contributed to the design of a new instrument"

\section{Verbs : design}

- intend or have as a purpose "She designed to go far in the world of business"

- conceive or fashion in the mind; invent

"She designed a good excuse for not attending classes that day"

- create designs

"Dupont designs for the house of Chanel"

- make a design of; plan out in systematic, often graphic form

"design a better mousetrap"; "plan the new wing of the museum"

- create the design for; create or execute in an artistic or highly skilled manner

"Chanel designed the famous suit" 
- design something for a specific role or purpose or effect

"This room is not designed for work"

- make or work out a plan for; devise

"They contrived to murder their boss"; "design a new sales strategy"; "plan an attack"

Who does need design?

Firms

For a commercial business it's well worth looking at whether firms offer is as worthwhile and enjoyable for customers as it can be. The better the experience the more they shell return.

Non-profit organizations

Who needs their services designed? Anybody who provides a service, whether within a physical environment - such as a hotel, school, airport, hospital or public transport system or through other means, for example a mobile phone, cable television, or online.

Public services (and administration)

Public sector organisations don 't need to make a profit in the same way but as it 's tax payers' money they 're spending, they too need to be as effective as possible. Providers like schools and hospitals have a duty to work even harder than commercial brands to create services that make people feel positive about the experiences they are having. Service design as a discipline also offers a response to the User Engagement agenda creating opportunities for users and front line providers of a service to work together to redesign and innovate the services they use.

\section{Value of design in economic perspective}

Adding value through design

Adding value to products and services makes businesses more successful. The more value they add to their core products and services, the better they do. But when they use design to add value, they do even better in a whole range of ways, including bigger profit, turnover and market share. The chart presented below shows dependencies between added value and design. If a business adds value to make what it offers more attractive to customers, it's likely to out-perform businesses which depend wholly on their core product or service. The research shows that the prospects are best of all, if one combines 'added value' with the use of 'design' or see design as integral to your business.

\section{Chart 2. Impact of added value on business performance}

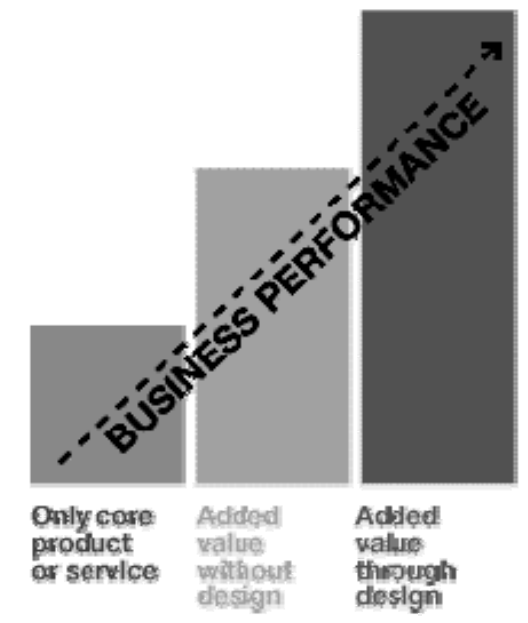

(Design Council, 2007, p.36) 


\section{Adding value in business}

Increasingly, businesses can't just rely on their core products and services to compete. They need something extra - added value - to help differentiate themselves from the competition and tempt new customers or keep the ones they've already got. The researchers of Continental Research conducted “Added Value Research 2007”, where they have focused on the methods businesses can use to make what they do stand out. They have broken the 'added value' category down, into the following eight activities (Design Council, 2007, p.36):

1. The retail experience - the shopping environment, the location and the opening times

2. Online services - web-based ordering systems or information on products and services

3. Physical services - fitting, installation, technical support or flexible delivery

4. Customer relationships - developed through after-sales service or knowledgeable staff

5. The design of products or services - improved quality, or customising to meet personal needs

6. Finance or insurance options

7. Developing a valued and trusted brand

8. Bundling products and services to create packages.

The research shows that the customer relationship is the most common route to added value, and $92 \%$ of businesses follow it. Not far behind is the design of products and services, where $84 \%$ of businesses say they add value in this way.

Chart 3. How do business add value to their core offer

\begin{tabular}{l|l}
\hline customer relationship & $92 \%$ \\
\hline design of product or service & $84 \%$ \\
\hline brand & $78 \%$ \\
\hline physical services & $59 \%$ \\
\hline online service & $57 \%$ \\
\hline product/service bundling & $56 \%$ \\
\hline retail experience & $56 \%$ \\
\hline partnerships & $50 \%$ \\
\hline finance options & $22 \%$ \\
\hline
\end{tabular}

(Design Council, 2007, p.37)

It is worth mentioning, that at least half of businesses add value in all the ways they were asked about, but far fewer actually declared to have a defined strategy for doing so.

\section{Impact of adding value on business}

The benefits of adding value are clear according to the referred research. The majority of businesses that add value see some impact across a range of measures. For example, nine out of ten businesses say it has had a positive impact on their competitiveness and $83 \%$ say it has boosted their turnover and profits. A significant proportion go further and say adding

\footnotetext{
1 The Added Value Research 2007 was conducted by Continental Research in November 2006 and published by Design Council.
} 
value has had a great impact on performance - a third say this applies to their competitiveness and nearly as many report a great impact on turnover. Almost a quarter say the same about the effect of added value on market share (24\%) and their ability to open up new markets (23\%).

Chart 4 . What is the overall impact of added value on business performance?

\begin{tabular}{lll}
\hline Competitiveness & & $90 \%$ \\
\hline some impact & $34 \%$ \\
\hline great impact & $83 \%$ \\
\hline Increased turnover & $29 \%$ \\
\hline some impact & $83 \%$ \\
\hline great impact & $18 \%$ \\
\hline Increased profit & $76 \%$ \\
\hline some impact & $24 \%$ \\
\hline great impact & \\
\hline Increased market share & $75 \%$ \\
\hline some impact & $23 \%$ \\
\hline great impact & \\
\hline Development of new markets & $54 \%$ \\
\hline some impact & $12 \%$ \\
\hline great impact & \\
\hline Increased employment & \\
\hline some impact & \\
\hline great impact & \\
\hline
\end{tabular}

(Design Council, 2007, p.37)

To find out how much adding value is worth to businesses, the researchers asked them to quantify its impact on their turnover, market share and profit. The results suggest that businesses which add value get an average 14\% increase in turnover and market share, while their profits go up by an average of $11 \%$.

Chart 5. Impact of added value on business performance
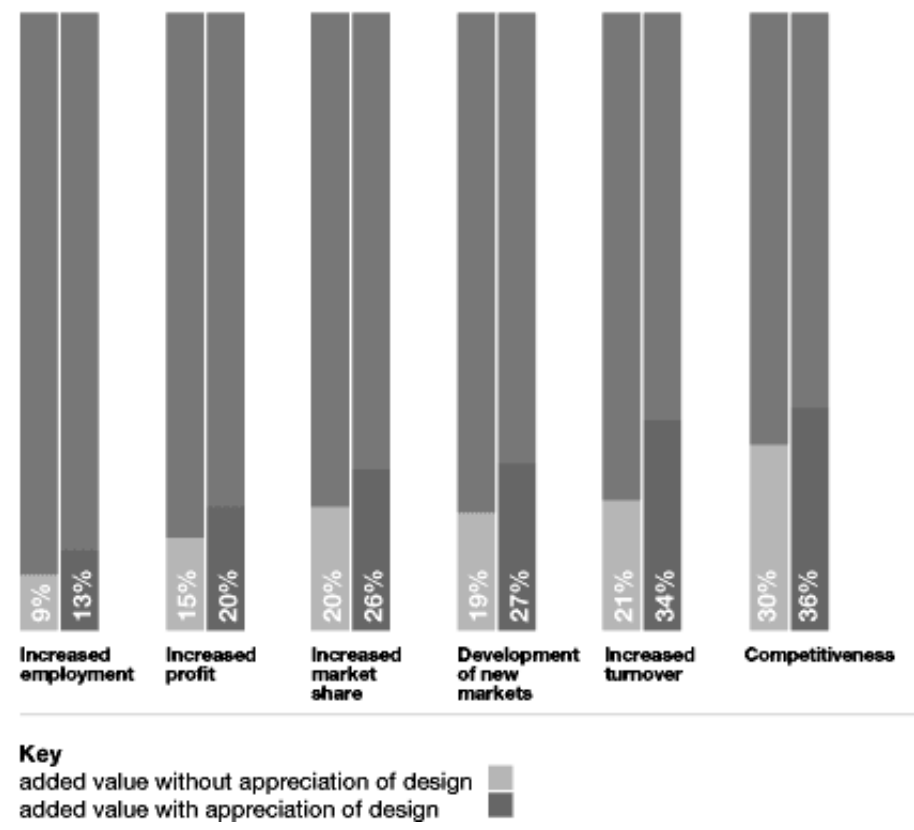

added value with appreciation of design

(Design Council, 2007, p.38) 
One third of businesses that add value through design say this has had a great impact on turnover. Businesses get even more benefit from adding value when they use design or a designer, aside from a fact whether they use design specifically for added value activity or see it as important to the business generally. Therefore, 34\% businesses that see design as integral or significant say added value has had a great impact on their turnover. Where design plays only a limited role, the proportion is just $21 \%$.

There is also a link between using design and being strategic about adding value. Almost half of businesses that use design, are planning to add more value in the future $(46 \%)$, compared to only $6 \%$ of those that don't use design.

\section{Impact of adding value by design on business performance}

$43 \%$ of businesses who used a designer to add value reported a great impact on competitiveness, compared to $25 \%$ of those who didn't use a designer.

$53 \%$ of businesses that use a designer also add a lot of value to their core product or service. In businesses that don't use a designer only $39 \%$ add a lot of value to their core product or service.

\section{Value of design in economic perspective} Impact of design on business performance

Design can have a positive effect on all business performance indicators, from turnover and profit to market share and competitiveness. Almost half of UK businesses believe design contributes to some extent to increased market share (46\%) and turnover (44\%). There are other indications shown on the chart below. Respondents declared positive contribution of design to business performance indicators like market share, turnover, new markets development, profit, competitiveness, new products and services as well as employment.

Chart 6. Extent of contribution of design to business performance over the past 12 months

\begin{tabular}{l|l}
\hline Increased market share & $46 \%$ \\
\hline to some extent & $7 \%$ \\
\hline to a great extent & $44 \%$ \\
\hline Increased turnover & $6 \%$ \\
\hline to some extent & $42 \%$ \\
\hline to a great extent & $6 \%$ \\
\hline Development of new markets & $42 \%$ \\
\hline to some extent & $7 \%$ \\
\hline to a great extent & $38 \%$ \\
\hline Increased profit & $7 \%$ \\
\hline to some extent & $37 \%$ \\
\hline to a great extent & $9 \%$ \\
\hline Competitiveness & $26 \%$ \\
\hline to some extent & $3 \%$ \\
\hline to a great extent & \\
\hline New products/services & \\
\hline to some extent & \\
\hline to a great extent & Increased employment \\
\hline to some extent & to a great extent \\
\hline
\end{tabular}

(Design Council, 2007, p.12) 


\section{Impact of design on the share prices of design-led business}

Research \& Information team of the Design Council conducted a comparative study where they have developed a directory of design-led businesses (Design Council, 2007, p.14). This directory - called the Design Index - contains household names, such as Barclays, Egg, Tesco, Marks \& Spencer, Boots, British Airways, EasyJet, Rolls-Royce, BP and Unilever. A sustained track record in design and innovation awards was the key criterion for inclusion. These robust requirements translate into a good external indication of the way a business uses and values design. The Index tracked the share prices of these businesses (and is regularly recalculated to take account of mergers and de-listings).

The Design Index - an index of 61 design-led businesses - has out-performed the FTSE 100 by more than $200 \%$ over the past decade. This proves that businesses using design effectively do better than their peers, by a long way, and over a long time. And it's clear evidence of a relationship between design investment, business performance and long-term stock market value.

Design Index is a comparative study, not an actual investment vehicle, but if it was, $£ 1,000$ invested in 1994 would result in return of 362,6\%, comparing to 157\% received on FTSE 100 index.

Table 1. Value on 29 December 2004 of $£ 1,000$ on 28 December 1994

\begin{tabular}{l}
...in the Design Index \\
\hline.. in the FTSE 100 \\
\hline
\end{tabular}

\section{$£ 3,626$} $\Sigma 1,570$

(Design Council, 2007, p.14)

Not only has the Design Index out-performed the FTSE 100, but that out-performance has been constant. The Index rose more in good times, and fell less in bad times.

Chart 7. Ten-Year Performance 1995-2004

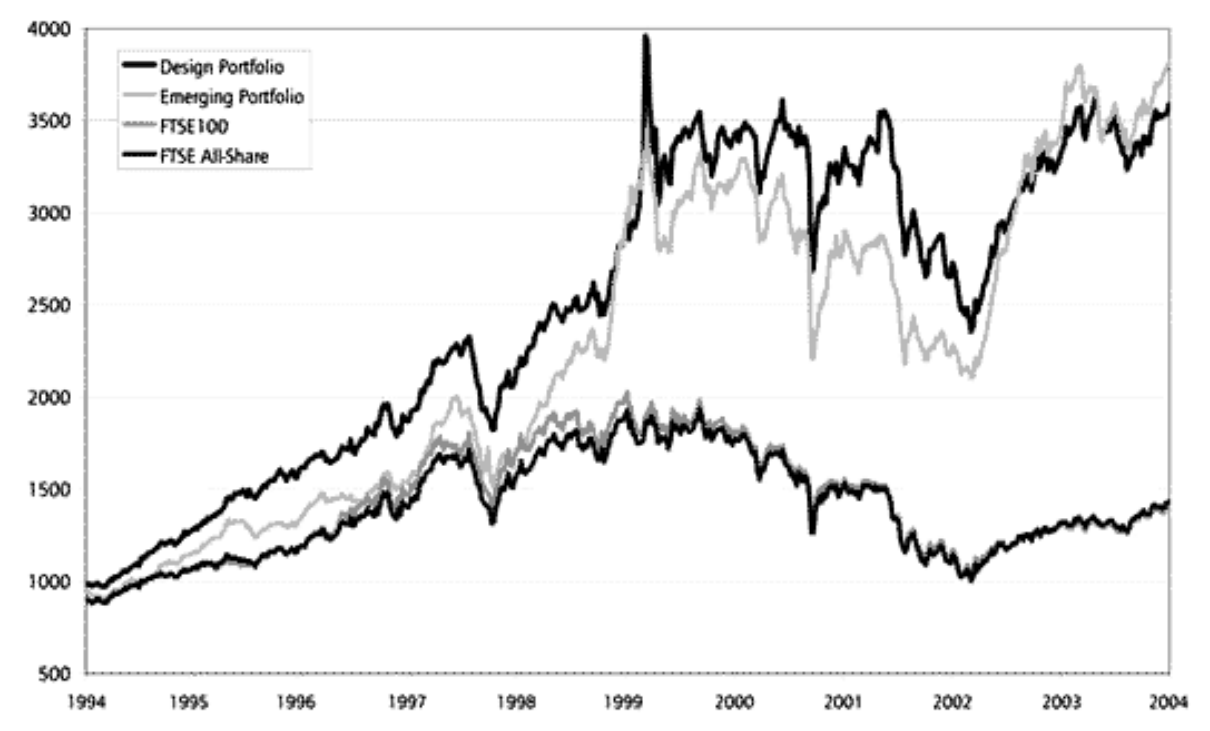

(Design Council, 2007, p.14) 
The difference hasn’t been fleeting or fluctuating, but solid over a decade.

\section{Conclusions}

The objective of the present paper was to point out the main aspects of design as creating value factor. Nowadays design, which is a very rich term, should be understood at the strategic level of application as a modern human activity that can help create the products and services of the future within the constraints of our context. Three subjects (firms, non-profit organizations and public services) with need for design were identified.

In the present paper we show dependencies between added value (which helps differentiate companies form the competition) and design, which are clear according to the referred in the paper research - design can have a positive effect on all business performance indicators, from turnover and profit to market share and competitiveness.

\section{REFERENCES:}

1. Livesey F., Molutrie J., (2009), International Design Scoreboard: Initial indicators of international design capabilities, Institute for Manufacturing, University of Cambridge, Cambridge.

2. King O., Heapy J., A Two Minute Guide to Service Design, http://www.enginegroup.co.uk/images/uploads/2_minute_guide_to_service_design.pdf:

May 03, 2009.

3. The Value of Design Factfinder Report, (2007), Design Council, London.

4. Margolin V. ed., Buchanan R. ed., The Idea of Design, (1996), MIT Press, Cambridge.

5. Runcie E., Service Design, http://www.designcouncil.org.uk: May 03, 2009.

6. Design, The Free On-line Dictionary of Computing, http://dictionary.reference.com: May 03, 2009.

7. Design, Thinkmap Visual Thesaurus, http://www.visualthesaurus.com/?ad=eaf: May 03, 2009.

8. Ranjan M.P., (2009), What is Design? Philosophy of Design and emerging insights with unfolding opportunities for the knowledge economy, National Institute of Design, Ahmedabad-India.

9. Nelson H., Stolterman E., (2003), The Design Way: Intentional Change in an Unpredictable World, Educational Technology Publications, New Jersey. 